\title{
AKTIVITAS DARI KUERSETIN SEBAGAI AGEN PENCERAH KULIT SECARA IN SILICO
}

\author{
K. D. Adnyani ${ }^{1}$, L. W. E. Lestari ${ }^{2}$, H. Prabowo ${ }^{1}$, P. A. I. A. Siaka ${ }^{1}$, dan N. P. L. Laksmiani ${ }^{1}$

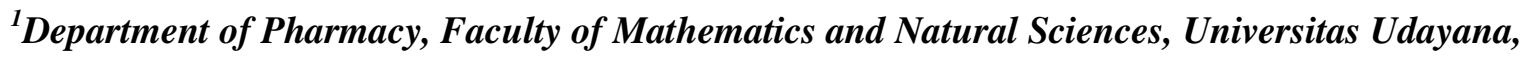 \\ Bukit Jimbaran, Badung, Bali, Indonesia \\ ${ }^{2}$ Central Laboratory of Universitas Udayana, Bukit Jimbaran, Badung, Bali, Indonesia \\ *e-mail: lindalaksmiani@gmail.com
}

\begin{abstract}
ABSTRAK
Peningkatan proses melanogenesis menyebabkan sintesis melanin yang berlebih sehingga terjadi penggelapan warna kulit. Proses melanogenesis membutuhkan enzim melanogenesis yang salah satunya adalah tyrosinaserelated protein 1. Salah satu senyawa flavonoid yang berpotensi sebagai agen pencerah kulit adalah kuersetin. Aktivitas antioksidan dari kuersetin berperan sangat penting dalam antimelanogenesis. Penelitian ini bertujuan untuk mengetahui afinitas dan mekanisme molekuler kuersetin terhadap protein target tyrosinase-related protein 1 menggunakan metode molecular docking secara in silico. Molecular docking dilakukan melalui tahapan antara lain optimasi struktur senyawa kuersetin, preparasi protein target tyrosinase-related protein 1, validasi metode molecular docking, dan docking kuersetin pada protein tyrosinase-related protein 1. Docking kuersetin dengan tyrosinase related-protein 1 menghasilkan nilai energi ikatan $-7,81 \mathrm{kkal} / \mathrm{mol}$, sedangkan docking native ligand dengan tyrosinase related-protein 1 menghasilkan nilai energi ikatan $-5,39 \mathrm{kkal} / \mathrm{mol}$. Kuersetin memiliki afinitas yang kuat terhadap tyrosinase related-protein 1 yang ditunjukkan dari nilai energi ikatan hasil docking. Kuersetin memiliki aktivitas sebagai agen pencerah kulit secara in silico dengan mekanisme molekuler melalui penghambatan terhadap aktivitas enzim tyrosinase related-protein 1.
\end{abstract}

Kata kunci : agen pencerah kulit, in silico, kuersetin, tyrosinase-related protein 1

\begin{abstract}
Increasing melanogenesis process causes excessive melanin synthesis resulting in darkening of the skin color. The melanogenesis process requires mealnogenesis enzymes, one of which is tyrosinase-related protein 1. One of the flavonoid compounds that has the potential as a skin lightening agent is quercetin. The antioxidant activity of quercetin plays a very important role in antimelanogenesis. This study aims to determine the affinity and molecular mechanism of quercetin on the target protein tyrosinase-related protein 1 using in silico molecular docking method. Molecular docking is carried out through stages including optimization of the structure of quercetin compounds, preparation of the target protein tyrosinase-related protein 1, validation of the molecular docking method, and docking of quercetin on the tyrosinase-related protein 1. Docking of quercetin with tyrosinase-related protein 1 produces binding energy values of $-7.81 \mathrm{kcal} / \mathrm{mol}$, while docking of native ligand with tyrosinase-related protein 1 produces binding energy values of $-5.39 \mathrm{kcal} / \mathrm{mol}$. Quercetin has a strong affinity for tyrosinase-related protein 1 which is indicated by the binding energy from the docking results. Quercetin has activity as a skin whitening agent with in silico test with molecular mechanisms through inhibition of the activity of tyrosinase-related protein 1 enzyme.
\end{abstract}

Keywords: skin whitening agent, in silico, quercetin, tyrosinase-related protein 1

\section{PENDAHULUAN}

Paparan sinar ultraviolet dalam waktu lama dengan frekuensi yang sering dapat menyebabkan gangguan pada kulit. Sinar ultraviolet dapat meningkatkan sintesis melanin di kulit dan menyebabkan hiperpigmentasi. Hiperpigmentasi merupakan suatu gangguan pada pigmen kulit yang umum terjadi karena adanya peningkatan proses melanogenesis yang dapat menyebabkan penggelapan warna kulit. Peningkatan sintesis melanin secara lokal atau tidak merata dapat menyebabkan pigmentasi lokal atau noda hitam pada bagian tertentu dari kulit wajah (Cayce et al., 2004).

Proses biosintesis melanin di dalam melanosom membutuhkan enzim melanogenesis salah satunya tyrosinase-related protein 1 (TRP 1). Fungsi spesifik dari enzim TRP 1 pada jalur melanogenesis adalah sebagai DHICA oksidase (Kobayashi et al., 
1994). TRP 1 berfungsi mengkatalisis oksidasi 5,6-dihydroxyindole-2-carboxylic acid (DHICA) menjadi eumelanin serta berperan dalam peningkatan rasio eumelanin/feomelanin (Videira et al., 2013; Anwar dkk., 2016). Menghambat pembentukan melanin merupakan salah satu cara yang dapat dilakukan untuk mencerahkan kulit (Lloyd et al., 2011). Pembentukan melanin dapat dihambat dengan cara menghambat aktivitas enzim tyrosinase-related protein 1 (Pankaja, 2013).

Salah satu tindakan yang dapat dilakukan untuk penanggulangan hiperpigmentasi pada kulit yaitu dengan menggunakan produk pencerah kulit. Zat yang umumnya digunakan sebagai pencerah kulit seperti hidrokuinon, asam azelat, merkuri dan asam kojat, namun beberapa senyawa tersebut memiliki efek samping berbahaya terkait karsinogenesis dan mutagenesis (Lin et al., 2008; Gazali et al., 2014). Oleh karena itu perlu dilakukan usaha untuk menemukan senyawa baru yang dapat digunakan sebagai bahan pencerah kulit yang aman dalam penggunaanya seperti pengembangan pencerah kulit dari bahan alam.

Salah satu senyawa bahan alam yang berpotensi sebagai agen pencerah kulit adalah kuersetin. Aktivitas antioksidan dari kuersetin berperan sangat penting dalam antimelanogenesis, karena kemampuannya dalam mengkelat ion logam (Kim dan Uyama, 2005; Choi dan Shin, 2016). Berdasarkan penelitian Arung et al. (2011), fraksinasi dari kulit bawang merah (Allium cepa) yang menghasilkan isolat kuersetin menunjukkan aktivitas penghambatan pembentukan melanin pada sel melanoma $\mathrm{B} 16$ dengan nilai $\mathrm{IC}_{50}$ sebesar 26,5 $\mu \mathrm{M}$.

Pengujian dilakukan untuk mengetahui afinitas dan mekanisme molekuler kuersetin terkait dengan aktivitasnya sebagai agen pencerah kulit menggunakan teknik kimia komputasi yaitu molecular docking. Molecular docking secara in silico dapat digunakan untuk uji pendahuluan (skrining) pada senyawa yang diduga memiliki aktivitas farmakologi, sehingga dapat diketahui struktur senyawa yang paling baik untuk dapat berikatan dengan reseptor (Mukesh dan Rakesh, 2011).

\section{BAHAN DAN METODE}

\section{Bahan}

Struktur senyawa kuersetin 3 dimensi yang diunduh pada https://pubchem.ncbi.nlm.nih.gov/. Struktur protein target enzim tyrosinase-related protein 1 (PDB ID: 5M8M) yang diunduh pada website Protein Data Bank (PDB) http://www.rcsb.org/pdb/home/home.do.

\begin{abstract}
Alat
Seperangkat komputer dengan spesifikasi Windows 1064 bit yang dilengkapi Hyperchem 8, Chimera 1.10.1, dan AutoDock Tools yang terdiri dari program Autodock 4.2 dan Autogrid.
\end{abstract}

\section{Metode Penelitian}

\section{Optimasi Struktur 3 Dimensi Senyawa Kuersetin}

Struktur 3 dimensi senyawa kuersetin dioptimasi menggunakan program Hyperchem 8. Optimasi dilakukan menggunakan metode komputasi semi-empiris AM1 (Austin Model 1) dan dilakukan kalkulasi dengan single point serta optimasi geometri (Laksmiani dan Nugraha, 2019).

\section{Preparasi Struktur 3 Dimensi Protein Tyrosinase-Related Protein 1}

Preparasi protein target dilakukan menggunakan program Chimera 1.10.1 dengan memisahkan struktur 3 dimensi protein tyrosinase-related protein 1 dengan native ligand-nya. Dilakukan pula penghilangan molekul air $\left(\mathrm{H}_{2} \mathrm{O}\right)$ pada protein target tyrosinase-related protein 1 (Laksmiani dan Nugraha, 2019).

\section{Validasi Metode Molecular Docking}

Validasi metode molecular docking dilakukan dengan cara men-docking-kan kembali native ligand pada protein target tyrosinase-related protein 1 menggunakan aplikasi AutoDock Tools (Autodock 4.2 dan Autogrid). Parameter validasi metode molecular docking adalah nilai RMSD (Root 
mean square distances) (Laksmiani dan Nugraha, 2019). Metode molecular docking dikatakan valid jika nilai RMSD $\leq 3,0 \AA$ (Jain dan Nicholls, 2008).

\section{Docking Kuersetin pada Protein Tyrosinase- Related Protein 1}

Senyawa kuersetin yang telah teroptimasi di-docking-kan pada protein target tyrosinaserelated protein 1 yang sudah dipreparasi (dihilangkan native ligand-nya) menggunakan aplikasi Autodock Tools dengan tahapan proses docking yang sesuai dengan validasi metode (Laksmiani dan Nugraha, 2019).

Hasil yang diperoleh dari molecular docking adalah nilai energi ikatan dan ikatan hidrogen. Energi ikatan digunakan untuk menganalisis afinitas dari kuersetin terhadap protein target tyrosinase-related protein 1 . Semakin rendah nilai energi ikatan maka ikatan tersebut semakin stabil dan kuat. Sedangkan ikatan hidrogen yang terbentuk digunakan untuk menganalisis mekanisme interaksi yang terjadi antara kuersetin dengan protein target (Laksmiani dan Nugraha, 2019).

\section{HASIL DAN PEMBAHASAN}

\section{Optimasi Struktur 3 Dimensi Senyawa Kuersetin}

Struktur 3 dimensi senyawa kuersetin dioptimasi menggunakan program Hyperchem 8 bertujuan untuk memperoleh struktur yang paling stabil dengan energi paling rendah. Optimasi senyawa kuersetin dilakukan dengan metode komputasi semi empiris AM1 (Austin Model 1) meliputi proses kalkulasi single point dan optimasi geometri. Kalkulasi single point adalah perhitungan yang digunakan untuk menentukan energi total molekul dari struktur kuersetin tanpa proses optimasi. Sedangkan optimasi geometri untuk meminimalisasi energi agar diperoleh struktur kuersetin yang paling stabil ditandai dengan penurunan nilai energi total struktur kuersetin (Fitriasari dkk., 2008).

Energi yang diperoleh saat dilakukan kalkulasi single point dan optimasi geometri pada struktur kuersetin berturut-turut adalah $3699,526275 \mathrm{kkal} / \mathrm{mol}$ dan $-3711,7329$ $\mathrm{kkal} / \mathrm{mol}$. Proses optimasi struktur senyawa dikatakan berhasil jika energi hasil optimasi geometri memiliki nilai lebih rendah dibandingkan kalkulasi single point. Berdasarkan hal tersebut, proses optimasi telah berhasil dan diperoleh struktur 3 dimensi kuersetin yang telah teroptimasi. Struktur 3 dimensi kuersetin hasil optimasi geometri dapat dilihat pada Gambar 1.

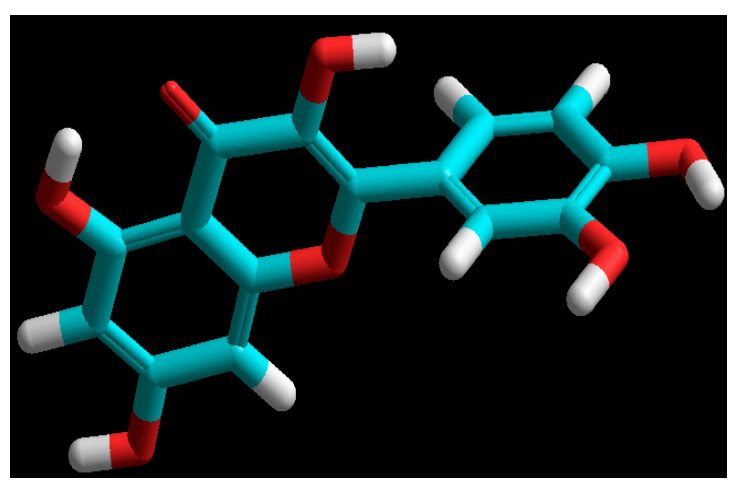

Gambar 1. Struktur 3 Dimensi Senyawa Kuersetin Hasil Optimasi

\section{Preparasi Protein Tyrosinase-Related Protein 1}

Preparasi protein tyrosinase-related protein 1 menggunakan program Chimera 1.10.1 dengan cara memisahkan protein dengan native ligand. Tujuan preparasi protein target yaitu memperoleh struktur protein target tanpa native ligand sehingga tersedia ruang/pocket untuk proses docking dan memperoleh struktur native ligand. Protein tyrosinase-related protein 1 (PDB ID: 5M8M) merupakan protein tyrosinase-related protein 1 intramelanosomal dari manusia. . Rantai yang dipilih adalah rantai $\mathrm{A}$ yang berikatan dengan native ligand kojic acid. Kojic acid adalah ligan yang berfungsi dalam menghambat aktivitas protein tyrosinase-related protein 1 (Lai et al., 2017).

Proses preparasi protein juga dilakukan penghilangan molekul air $\left(\mathrm{H}_{2} \mathrm{O}\right)$ yang bertujuan untuk menyisakan asam amino pada protein target sehingga saat proses docking yang berinteraksi hanya senyawa uji dengan asam amino (Huey et al., 2012). Molekul air harus dihilangkan agar dapat memaksimalkan interaksi antara senyawa uji dengan protein target (Kitchen et al., 2004). Struktur 3 dimensi protein tyrosinase-related protein 1 tanpa native ligand dan struktur native ligand kojic acid ditampilkan pada Gambar 2. 


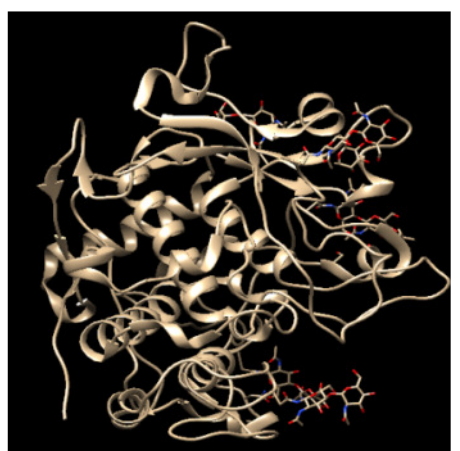

(a)

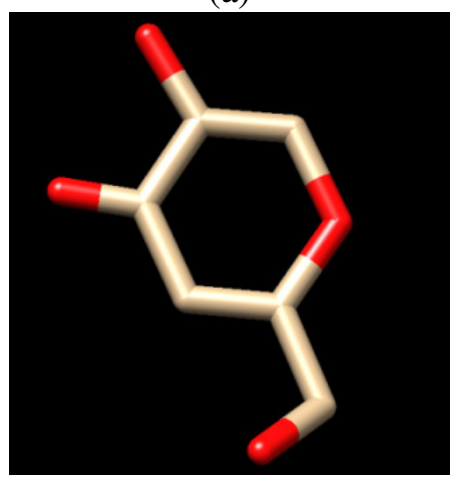

(b)

Gambar 2. Struktur 3 Dimensi Protein Tyrosinase-Related Protein 1 Tanpa Ligan (a) dan Native Ligand Kojic Acid (b)

\section{Validasi Metode Molecular Docking}

Validasi metode molecular docking dilakukan dengan cara men-docking-kan kembali (redocking) native ligand kojic acid pada protein target tyrosinase-related protein 1 yang sudah dipreparasi menggunakan aplikasi AutoDock Tools. Parameter validasi metode molecular docking adalah nilai RMSD (Root Mean Square Deviation). RMSD adalah pengukuran dua pose dengan cara membandingkan posisi atom antara struktur eksperimental terhadap struktur yang didocking atau yang diprediksi (Hawkins et al., 2008).

Metode dikatakan valid apabila diperoleh nilai RMSD $\leq 3 \AA$ (Jain dan Nicholls, 2008). Proses redocking protein tyrosinase-related protein 1 dengan native ligan-nya menghasilkan nilai RMSD sebesar 2,33 $\AA$. Nilai RMSD tersebut berada di bawah $3 \AA$ yang menunjukkan bahwa metode molecular docking ini valid dan memenuhi persyaratan parameter validasi metode molecular docking. Interaksi antara native ligand dengan protein tyrosinase-related protein 1 dapat dilihat pada Gambar 3.

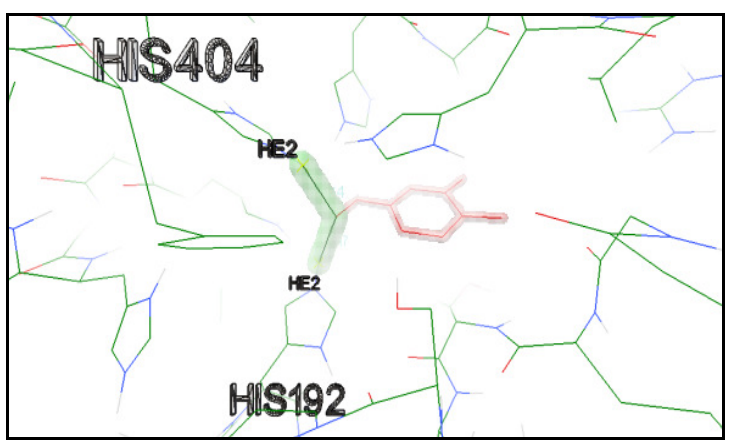

Gambar 3. Visualisasi Interaksi antara Native Ligand Kojic Acid dengan Protein Tyrosinase-Related Protein 1

\section{Docking Kuersetin pada Protein HER-2}

Kuersetin yang telah teroptimasi didocking-kan dengan protein tyrosinase-related protein 1 yang telah dipreparasi menggunakan Aplikasi AutoDock Tools. Koordinat kuersetin pada sisi aktif protein target diatur agar sama dengan koordinat native ligand pada protein target. Koordinat tersebut sudah tervalidasi karena sudah memenuhi persyaratan parameter validasi RMSD untuk metode molecular docking.

Docking antara kuersetin dengan protein tyrosinase-related protein 1 menghasilkan nilai energi ikatan sebesar $-7,81 \mathrm{kkal} / \mathrm{mol}$. Sedangkan docking antara native ligand dengan protein tyrosinase-related protein 1 menghasilkan nilai energi ikatan sebesar -5,39 $\mathrm{kkal} / \mathrm{mol}$. Energi ikatan pada proses docking berkaitan dengan interaksi dan afinitas ikatan senyawa uji terhadap protein target (Pratoko, 2012). Nilai energi ikatan yang semakin rendah menunjukan tingkat kestabilan atau kekuatan ikatan antara senyawa uji dengan protein target semakin baik, sehingga afinitasnya untuk berikatan semakin besar (Diyah dkk., 2013; Syahputra dkk., 2014).

Perbandingan hasil docking kuersetin dan native ligand dengan protein tyrosinase-related protein 1 menunjukkan bahwa energi ikatan kuersetin pada protein tyrosinase-related protein 1 lebih rendah dibandingkan nilai energi ikatan native ligand. Hasil tersebut menunjukkan bahwa afinitas dari kuersetin terhadap protein tyrosinase-related protein 1 lebih besar dibandingkan dengan afinitas dari native ligand dengan protein tyrosinase-related protein 1 .

Kuersetin menunjukkan interaksi terhadap enzim tyrosinase-related protein 1 melalui ikatan hidrogen pada asam amino 
ARG374, SER 394, dan ARG321. Ikatan hidrogen memberikan kontribusi terhadap afinitas senyawa uji dengan protein target (Rachmania dkk., 2016). Interaksi antara kuersetin dengan protein tyrosinase-related protein 1 dapat dilihat pada Gambar 4.

Tabel 1. Hasil Docking Kuersetin pada Protein Tyrosinase-Related Protein 1

\begin{tabular}{|c|c|c|c|}
\hline $\begin{array}{c}\text { Protein } \\
\text { Target }\end{array}$ & Ligan & $\begin{array}{c}\text { Energi } \\
\text { Ikatan } \\
(\mathrm{kkal} / \mathrm{mo} \\
\mathrm{l})\end{array}$ & $\begin{array}{c}\text { Ikatan } \\
\text { Hidroge } \\
\text { n }\end{array}$ \\
\hline \multirow{2}{*}{$\begin{array}{l}\text { Tyrosinas } \\
\text { e-Related } \\
\text { Protein } 1\end{array}$} & $\begin{array}{l}\text { Native } \\
\text { ligand }\end{array}$ & $-5,39$ & $\begin{array}{l}\text { HIS192 } \\
\text { HIS404 } \\
\end{array}$ \\
\hline & Kuersetin & $-7,81$ & $\begin{array}{c}\text { ARG374 } \\
\text { SER394 } \\
\text { ARG321 }\end{array}$ \\
\hline
\end{tabular}

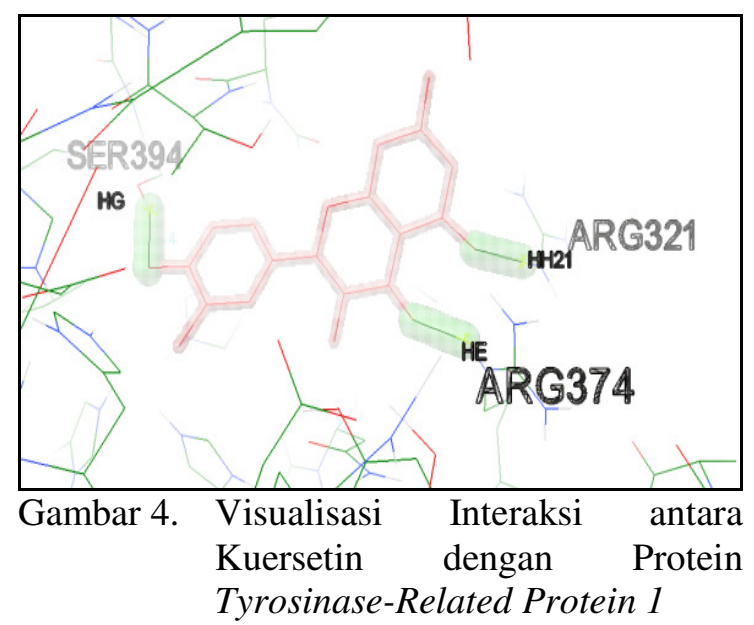

\section{KESIMPULAN}

Kuersetin memiliki afinitas yang kuat terhadap protein tyrosinase-related protein 1, yang ditunjukkan dari nilai energi ikatan hasil docking. sebesar $-7,81 \mathrm{kkal} / \mathrm{mol}$. Kuersetin memiliki aktivitas sebagai agen pencerah kulit secara in silico dengan mekanisme molekuler melalui penghambatan terhadap aktivitas enzim tyrosinase-related protein 1.

\section{UCAPAN TERIMA KASIH}

Penulis mengucapkan terima kasih kepada dosen pembiming, keluarga, temanteman, dan semua pihak yang telah membantu dan mendukung dalam menyelesaikan penelitian ini.

\section{DAFTAR PUSTAKA}

Anwar, A. I., Zainuddin, F., dan Miranti, A. 2016., Melesma, Makassar: 21 Press.

Arung, E. T., Furuta, S., Ishikawa, H., Kusuma, I. W., Shimizu, K., dan Kondo, R. 2011., Anti-melanogenesis properties of quercetin- and its derivative-rich extract from Allium cepa. Food Chemistry, 124: 10241028.

Cayce, K. A., McMichael, A. J., dan Feldman, S R. 2004. Hyperpigmentation: An Overview of The Common Afflictions. Dermatol Nursing, 16: 401-416.

Choi, M. dan Shin, H. 2016. AntiMelanogenesis Effect of Quercetin. Cosmetics, 3: 1-16.

Diyah, N. W., Siswandono, S. H., dan Purwanto, B. T. 2013. Pemodelan Molekul dan Hubungan Kuantitatif Struktur-Aktivitas Sitotoksik Turunan Benzoilurea sebagai Antitumor. Berkala Ilmiah Kimia Farmasi, 2.

Fitriasari, A., Wijayanti, N. K., Ismiyati, N., Dewi, D., Kundarto, W., Sudarmanto, B. S. A., dan Meiyanto, E. 2008. Studi Potensi Kurkumin dan Analognya sebagai Selective Estrogen Receptor Modulator (SERMs): Docking pada Reseptor Estrogen B. Pharmacon, 9.

Gazali, M., Zamani, N. P., dan Batubara, I. 2014. Potensi Limbah Kulit Buah Nyirih Xylocarpus granatum sebagai Inhibitor Tirosinase. Depik, 3: 187194.

Hawkins, P., Warren, G., Skillman, A., dan Nicholls, A. 2008. How to do an Evaluation: Pitfalls and Traps. Journal of Computer-Aidid Molecular Design, 22: 179-190.

Huey, R., Morris, G. M., dan Forli, S. 2012. Using AutoDock 4 and AutoDock Vina with AutoDockTools: A Tutorial, California: The Scripps Research Institute.

Jain, A. J., dan Nicholls, A. 2008. Recommendations for evaluational methods,. J. Comput. Aided Mol, 22: 133-139.

Kim, Y. J. dan Uyama, H. 2005. Tyrosinase inhibitors from natural and synthetic sources: structure, inhibition mechanism and perspective for the 
future. Cellular and Molecular Life Sciences, 62: 1707-1723.

Kitchen, D. B., Decornez, H., Furr, J. R., dan Bajorath, J. 2004. Docking and Scoring in Virtual Screening in Drug Discovery, Methods and Applications. Nat. Rev. Drug Discov, 3: 935-949.

Kobayashi, T., Urabe, K., Winder, A., Jimenez-Cervantes, C., Imokawa, G., Brewington, T., Solano, F., GarciaBorron, J. C., dan Hearing, V. J. 1994. Tyrosinase related protein 1 (TRP1) functions as a DHICA oxidase in melanin biosynthesis. The EMBO Journal, 13 (24): 5818-5825.

Lai, X., Wichers, H. J., Lopez, M. S., dan Dijkstra, B. W. 2017. Structure of Human Tyrosinase Related Protein 1 Reveals a Binuclear Zinc Active Site Important for Melanogenesis. Angew. Chem. Int, 56: 9812 -9815.

Laksmiani, N. P. L. dan Nugraha, I. P. W. 2019. Depigmentation Activity of Secang (Caesalpinia sappan L.) Extract Through Tyrosinase, Tyrosinase Related Protein-1 and Dopachrome Tautomerase Inhibition. Biomed Pharmacol J, 12(2).

Lin, J., Chiang, H., Lin, Y., dan Wen, K. 2008. Natural Products with Skin-Whitening Effects. Journal of Food and Drug Analysis, 16: 1-10.
Lloyd, H. W., Jenna, N. dan Kammer, B. A. 2011. Treatment of Hyperpigmentation. Semin Cutan Med Surg, 30: 171-175.

Mukesh dan Rakesh. 2011. Molekular Doking: A Review. International Journal of Research in Ayurveda \& Pharmacy, 2: 1746-1751.

Pankaja, S. C. 2013. Phytochemical Analysis Of Citrus sinensis Peel. International Journal of Pharma and Bio Sciences, 4 (1): 339-343.

Pratoko, D. K. 2012. Molecular Docking Turunan Kalkon terhadap Reseptor Estrogen $\beta$ (Er- $\beta)$ sebagai Antikanker Payudara. JKTI, 14: 20-25.

Rachmania, R. A., Supandi, dan Cristina, F. A. D. 2016. Analisis Penambatan Molekul Senyawa Flavonoid Buah Mahkota Dewa (Phaleria macrocarpa (Scheff.) Boerl.) pada Reseptor $\alpha$ Glukosidase sebagai Antidiabetes. Pharmacy, 13: 239-251.

Syahputra, G., Ambarsari, L., dan Sumaryada, T. 2014. Simulasi Docking Kurkumin Enol, Bisdemetoksikurkumin dan Analognya sebagai Inhibitor Enzim12Lipoksigenase. Jurnal Biofisika, 10: 55-67.

Videira, I. F. S., Moura, D. F. L., dan Magina, S. 2013. Mechanisms Regulating Melanogenesis. An Bras Dermatol, 88:76. 